\title{
TOWARDS UNDERSTANDING ACADEMIC INTEGRITY POLICY AMONGST HUNGARIAN HIGHER EDUCATION INSTITUTIONS
}

Gabor Laszlo

\begin{abstract}
This study is the first undertaking of its kind in Hungary, a statistical overview of the practices of Hungarian higher education institutions regarding academic integrity. The study was conducted at the leadership level of these institutions. The survey has multiple simultaneous goals. It was conceived to fill a gap in the information on academic integrity at the national level of Hungarian higher education, paying attention to the currently implemented anti-plagiarism practices and software, as well as to the operation of their repositories. The results and correlations show by this study indicate that there is much to be done in this field, but it is clear that Hungarian higher education institutions are on board with working together and moving forward.
\end{abstract}

Key words: Academic Integrity in Hungary, Survey Preliminary Results, Plagiarism Policies

\section{Introduction}

Hungary did not escape the plagiarism crisis that involved the politicians of many countries at the start of the 2o10s, however, this at least moved the issue into the public eye. The response to the phenomena [plagiarism] by universities was fulfilled by the creation of ethical rules and utilization of multiple forms of plagiarism-detecting software, and Hungarian higher education believed the issue to be solved. The university in question, mainly due to cost issues, would have liked to extend this solution to plagiarism to the national level. This came to be in 2017, when the Hungarian Rectors' Conference (HRC) created a working group to coordinate tasks regarding plagiarism.

\section{Literature Review}

Plagiarism and academic dishonesty are only a part of academic integrity. There is actually no word-for-word equivalent of the phrase "academic integrity" in Hungarian, it can only be described with related words. This paper uses the definition as put forward by ENAI for academic integrity "Compliance with ethical and professional principles, standards, practices and consistent system of values, that serves as guidance for making decisions and taking actions in education, research and scholarship."

The Impact of Policies for Plagiarism in Higher Education Across Europe (IPPHEAE, 2013) conducted from 2010-2013 was a European-level study, however, it did not produce significant results for Hungary. There is a very limited amount of prior Hungarian studies and publications that deal with this topic from the past decade. The available studies investigated academic dishonesty in specific disciplines from a 
teacher/student perspective, within specific topics, institutions, or the researcher's own team, mostly in Hungarian.

The Hungarian Academy of Sciences organized a conference on October 24th of 2013 with the name "Academic Ethics in Europe and Hungary", where László Fésüs, the Academy's academic integrity commission's president gave a presentation with the title "Academic integrity challenges and responses in Hungary and in Europe". He pointed out that "disregarding the Academy's Academic Integrity Code of Ethics, Hungarian academic integrity rules are accidental, there is no unified system, and ethics teaching is missing from universities and PhD programs." Barna Mezey, the then president of the Hungarian Rector's Conference, analysed various questions regarding Hungarian higher education's responsibility towards academic integrity. As he highlighted, the Act on National Higher Education only deals with academic integrity with a few points, it does not provide concrete rules. "The law does not provide any sanctions; thus it tasks institutions with solving the problem". The presentations' edited versions were published in Journal of Hungarian Science. (Fésüs, 2014, p. 647; Mezey, 2014, p. 66o)

The Future of Higher Education Research Centre at the Budapest Business School had a project about "Analysing perceptions about student cheating". Their topic focused on "the exploration of the phenomenon, causes and effects of student cheating in the two affected groups, those of teachers and students." Most recent publications can be found on the Research Centre webpage in Hungarian and English. (Future of Higher Education Research Centre (FHERC) at Budapest Business School (BBS), n.d.)

The author has studied plagiarism since 2010, and academic integrity more broadly at the University of Óbuda, where he was the first in the country to coordinate the implementation of a university-wide complex text-matching (called plagiarism-finding at the time) system, that was integrated with the university's digital repository of academic papers. His work in this field led to his membership in the Hungarian Rectors' Conference (HRC) working group, which is in charge of coordinating tasks regarding plagiarism. Thus, an opportunity arose to create a national-level survey of the competencies and attitudes of Hungarian higher education institutions, with the support of the HRC.

\section{Research aims and objectives}

This empirical research has multiple simultaneous goals. It was conceived to fill a gap in the information on academic integrity at the national level of Hungarian higher education, paying attention to the operation of institutions' repositories, as well as to the currently implemented anti-plagiarism practices and software. The survey also has the goal of serving as an assessment of the implementation of a possible national level system in the future, as demonstrated by good examples from Slovakia and Slovenia. (Kravjar, \& Noge, 2013; Ojsteršek et al., 2014)

\section{Methodology}

The survey comprised elements from the following international surveys: AIRS (The Academic Integrity Rating System), IPPHAEA, SEPPHAI. The document titled Electronic Detection of Plagiarism in Finnish Higher Education Institutions, 2013 provided 
a starting point for questions regarding a given country's centralized national system. Through a series of e-mails with the author of the IPPHEAE report - Plagiarism Policies in Hungary, its Hungarian and English questions were obtained, and it provided a starting point for the current survey. (Irene Glendinning personal communication, March 20. 2018, Re: Questionnaires) Furthermore, valuable information from the "Surveying academic integrity: Methodological issues and lessons learned" workshop at the 2019 ENAI conference in Vilnius further aided the development of the survey, largely in the areas of survey design and risk assessment/mitigation.

The first step of the survey was to find and contact the institutions with an online survey form. Throughout the summer of 2019, HRC sent a letter to the rectors of higher education institutions which contained the objectives of the survey, its structure, highlighted the importance of informed consent, and asked them to designate someone to fill out the survey for their institution. The designated person received the survey at the beginning of September 2019 as a link. Due to the length and complexity of the survey, the survey email included a unique identifier (token), that ensured that the respondent could stop and save their progress, and it provided the opportunity to finish the survey at a later date.

Informed consent was extremely important throughout the survey process, since the respondents' fear of damage to their reputation had to be minimized. The survey was not done anonymously. This was reasoned to be appropriate as the committee is interested in personally visiting the institutions in the future to conduct more precise research, thus the study asked for a personal contact, who tended to be the one filling out the survey. After the closure of the survey, data was pseudo-anonymized, and stored in this form. The results are published in aggregated form.

The online survey was sent in a form that could be saved and continued through the survey platform used by the University. This provides sufficient privacy and security for the data. This was necessary due to the complexity and length of the survey. In the interest of more precise data, we asked respondents to contact those colleagues (leader, librarian, etc.) if they believe that someone is more informed or better able to answer a question regarding the institution, in the same way as AIRS.

\section{Structure of the Survey}

The survey encompassed three broad categories. The first was academic ethics, more specifically the institutional rules, procedures, and sanctions regarding plagiarism. The second was institutional repositories, where questions were asked about the storage of students' theses. The third section contained questions regarding antiplagiarism systems, with emphasis on the need for such systems. In the case that certain institutions already used such software, they were asked about experience with the system, and whether it met their needs.

\section{Results and Discussion}

Reponses to the survey took much longer than expected, and involved multiple reminders sent to the respondents. The initial plan had the deadline as October 1st, 2019; however, this was extended as multiple responses arrived citing a high workload 
at the start of the semester, making it difficult to finish on time. There were also technical problems throughout the process. The goal became obtaining the highest possible response rate, thus, after multiple extensions, the data collection was closed at mid of March 2020, just as the pandemic situation arose.

The 1st attachment of the Act CCIV of 2011 on National Higher Education, contains a list of the recognised higher education institutions in Hungary, the number of which is 65, divided into 6 sub-categories as follows: State (public) universities, Private universities, State universities of applied sciences, Private universities of applied sciences, State colleges of education, Private colleges of education. This list does not include non-Hungarian higher education institutions having a branch campus in Hungary. The different categories are shown in Tables 1 and 2.

After multiple contacts, eventually 53 institutions delegated a survey respondent, out of which 51 institutions completed the survey. We received a total of 53 responses, as 1 institution sent two responses from geographically separated departments, while in another case the library answered specific questions. In both cases the data was able to be merged, leading to the total of 51 institutional responses.

Table 1

Recognised higher education institutions in Hungary by categories

\begin{tabular}{|l|c|c|c|c|}
\hline Categories & $\begin{array}{c}\text { Completed } \\
\text { Survey/ } \\
\text { Total Number } \\
\text { of Institutions }\end{array}$ & $\begin{array}{c}\text { Statistical } \\
\text { number of } \\
\text { students }\end{array}$ & $\begin{array}{c}\text { Number of } \\
\text { students at } \\
\text { respondent } \\
\text { institutions }\end{array}$ & $\begin{array}{c}\% \\
\text { Number of } \\
\text { students }\end{array}$ \\
\hline State (public) universities & $21 / 21(100 \%)$ & 202064 & 202064 & $100 \%$ \\
\hline Private universities & $6 / 8(75 \%)$ & 30128 & 29809 & $99 \%$ \\
\hline State universities of applied sciences & $5 / 5(100 \%)$ & 32672 & 32672 & $100 \%$ \\
\hline Private universities of applied sciences & $4 / 4(100 \%)$ & 10429 & 10429 & $100 \%$ \\
\hline State colleges of education & $1 / 1(100 \%)$ & 407 & 407 & $100 \%$ \\
\hline Private colleges of education & $14 / 26(53,78 \%)$ & 9410 & 5420 & $58 \%$ \\
\hline Total & $51 / 65(78,46 \%)$ & 285110 & 280801 & $98,49 \%$ \\
\hline
\end{tabular}

Source: Educational Authority. Statistical number of students as of 15 October 2019, Survey results

Table 2

Recognised higher education institutions in Hungary by Managing Authority

\begin{tabular}{|l|c|c|c|c|}
\hline Managing Authority & $\begin{array}{c}\text { Completed } \\
\text { Survey/ } \\
\text { Total Number } \\
\text { of Institutions }\end{array}$ & $\begin{array}{c}\text { Statistical } \\
\text { number of } \\
\text { students }\end{array}$ & $\begin{array}{c}\text { Number of } \\
\text { students at } \\
\text { respondent } \\
\text { institutions }\end{array}$ & $\begin{array}{c}\% \\
\text { Number of } \\
\text { students }\end{array}$ \\
\hline State & $27 / 27$ & 235143 & 235143 & $100 \%$ \\
\hline Private (non-religious) & $10 / 14$ & 26807 & 25122 & $93,7 \%$ \\
\hline Private (religious) & $14 / 24$ & 23160 & 20536 & $88,7 \%$ \\
\hline Total & $51 / 65$ & 285110 & 280801 & $98,49 \%$ \\
\hline
\end{tabular}

Sources: Educational Authority. Statistical number of students as of 15 October 2019, Survey results 
"Higher education programmes in Hungary are offered by universities and colleges. In accordance with the common European higher education principles, Hungary introduced the three-cycle degree structure in 2006 (BA/BSc, MA/MSc, and PhD/DLA)." (Hungarian Rectors Conference, 2015)

The overall completion rate out of Hungarian higher education is $78.5 \%$ ( 51 of 65 ).

Since there are large variations in the number of students at different institutions, the number of students at the institutions that completed the survey is showed as a basevalue. The data on student enrolment is from the official statistics on Hungarian higher education provided by the Department for Training in Higher Education, Ministry for Innovation and Technology.

The students attending institutions that responded to the survey comprise $98.49 \%$ of Hungarian students in higher education. With one exception, all institutions with more than 1000 students completed the survey. Based on the Educational Authority information, the statistical number of students includes the active, primary number of students in current programs as of the statistical deadline. If a student is part of multiple programs at an institution, they only appear once in the data. In the case that a student is in multiple programs at multiple institutions, then each institution is counted once. Thus, the data does not correspond exactly with the physical number of students in the country. (According to the ISCED 2011 numbered classifications for higher education; 5: Post-Secondary Professional Programs; 6: College Programs, Bachelor's Degrees (BA/BSc) and related professional certifications; 7: University Programs, Master's Degrees (MA/MSc), Unified Programs and related professional certifications; 8: Doctoral Degrees (PhD/DLA))

\section{Institutional rules, procedures}

The first part of the survey included questions on institutional rules and procedures regarding academic integrity and plagiarism.

In the conference mentioned above in the literature review, the then-president of the HRC (in 2013) presented the results of a study conducted in 26 universities: 10 universities had a code of ethics, 2 universities were about to adopt one or planned to in the future, 14 universities had no code of ethics. Out of these, 3 universities had multiple rules regulating the issue, while in a few situations ethical boards or rules were organized on a departmental level "On the question of plagiarism, they wished to adopt stricter principles.” (Mezey, 2014, p. 658)

According to the new survey, regarding universities $(n=38), 34$ responded that they have a code of ethics, and with one exception they all provided links to them on their respective institutional websites. Two universities responded that it does not know. A further 3 universities responded with a simple no. (Due to institutional changes the number of universities has significantly increased since 2013, this is the cause of the increased number of universities in this study.) 
Table 3

Does the institution have a code of ethics?

\begin{tabular}{|l|c|c|}
\hline Possible answers & Frequency & Percent \\
\hline Yes & 37 & 72,5 \\
\hline No & 12 & 23,5 \\
\hline I do not know & 2 & 3,9 \\
\hline Total & 51 & 100,0 \\
\hline
\end{tabular}

Table 4

When was the code of ethics implemented at the institution

\begin{tabular}{|l|c|c|}
\hline Possible answers & Frequency & Percent \\
\hline Less than 1 year ago & 2 & 5 \\
\hline 1-2 years ago & 3 & 8 \\
\hline 3-4 years ago & 9 & 24 \\
\hline 5+ years ago & 23 & 62 \\
\hline Total & 37 & 100 \\
\hline
\end{tabular}

The above tables (Table 3, Table 4) show that those institutions that responded in 2013 that they would implement a code of ethics since have done so.

Table 5

Institution has rules and procedures regarding the handling of plagiarism

\begin{tabular}{|l|c|c|}
\hline Possible answers & Frequency & Percent \\
\hline Yes, as part of other rules & 33 & 64,7 \\
\hline Yes, with separate rules & 7 & 13,7 \\
\hline No & 9 & 17,6 \\
\hline I do not know & 2 & 3,9 \\
\hline Total & 51 & 100,0 \\
\hline
\end{tabular}

Regarding the universities, 4 do not have rules regarding plagiarism, however, they do have a code of ethics (Table 5 vs Table 3 ). Of the total sample of 40,9 institutions have rules on plagiarism, but no code of ethics.

Looking at the dates of implementation of the code of ethics (Table 6), it can be determined that the rules on plagiarism were implemented before the code of ethics.

Table 6

When were the rules on plagiarism implemented at the institution?

\begin{tabular}{|l|c|c|}
\hline Possible answers & Frequency & Percent \\
\hline Less than 1 year ago & 1 & 3 \\
\hline 1-2 years ago & 3 & 8 \\
\hline 3-4 years ago & 6 & 15 \\
\hline 5+ years ago & 29 & 74 \\
\hline Total & 39 & 100 \\
\hline
\end{tabular}


Table 7

The institution has taken concrete steps against plagiarism by students

\begin{tabular}{|l|c|c|}
\hline Possible answers & Frequency & Percent \\
\hline Yes & 32 & 62,7 \\
\hline No & 8 & 15,7 \\
\hline I do not know & 11 & 21,6 \\
\hline Total & 51 & 100,0 \\
\hline
\end{tabular}

The respondents that answered "No" to the question "The institution has taken concrete steps against plagiarism by students" (Table 7) were asked to express their opinion on what steps must be taken and in what direction. Many of the respondents emphasized a need for the following: the creation of a unified set of rules, better dissemination of information, preparation, effective help with software, and the "automation" of checking.

Table 8

Change in the number of plagiarism-related cases at the institutional level in the past years

\begin{tabular}{|l|c|c|}
\hline Possible answers & Frequency & Percent \\
\hline Significantly decrease & 3 & 5,9 \\
\hline Slight decrease & 14 & 27,5 \\
\hline No change & 13 & 25,5 \\
\hline Slight increase & 2 & 3,9 \\
\hline I do not know/Do not wish to judge & 19 & 37,3 \\
\hline Total & 51 & 100,0 \\
\hline
\end{tabular}

Table 8 shows that no respondent chose the "significant increase" option to the question regarding to "Change in the number of plagiarism-related cases at the institutional level in the past years". Out of those that considered their institution to be taking determined steps to combat plagiarism, 3 indicated a significant decrease, while 9 did not know/refused to provide a judgement. We further asked how much the respondents relied on internal quantitative data from their institution, and whether such data on instances of plagiarism and its consequences is registered by their institution. (Table 9.)

Table 9

Institutional registry of instances of plagiarism and consequences

\begin{tabular}{|l|c|c|}
\hline Possible answers & Frequency & Percent \\
\hline Exists & 8 & 15,7 \\
\hline Does not exist & 33 & 64,7 \\
\hline I do not know & 10 & 19,6 \\
\hline Total & 51 & 100,0 \\
\hline
\end{tabular}

With the following questions, the goal was to find out whether, according to the respondent's opinion, their institution provides training for teachers, researchers, and students. The results are shown in the following tables (Table 10-13). 
Table 10

The institution provides training on academic ethics for the administrative workers, teachers, researchers, and assistants

\begin{tabular}{|l|c|c|}
\hline Possible answers & Frequency & Percent \\
\hline Yes & 12 & 23,5 \\
\hline No & 33 & 64,7 \\
\hline I do not know & 6 & 11,8 \\
\hline Total & 51 & 100,0 \\
\hline
\end{tabular}

Table 11

In your opinion, is more training necessary for teachers/researchers and other staff regarding academic integrity?

\begin{tabular}{|l|c|c|}
\hline Possible answers & Frequency & Percent \\
\hline Yes & 31 & 60,8 \\
\hline No & 13 & 25,5 \\
\hline I do not know/Do not wish to answer & 7 & 13,7 \\
\hline Total & 51 & 100,0 \\
\hline
\end{tabular}

Table 12

Does the institution provide training opportunities related to academic ethics (ex. Avoiding plagiarism, research methods, citation methods, etc.) for students?

\begin{tabular}{|l|c|c|}
\hline Possible answers & Frequency & Percent \\
\hline Yes & 44 & 86,3 \\
\hline No & 5 & 9,8 \\
\hline I do not know & 2 & 3,9 \\
\hline Total & 51 & 100,0 \\
\hline
\end{tabular}

Table 13

In your opinion, is more training necessary for students on academic integrity (ex. Avoiding plagiarism)?

\begin{tabular}{|l|c|c|}
\hline Possible answers & Frequency & Percent \\
\hline Yes & 33 & 64,7 \\
\hline No & 13 & 25,5 \\
\hline I do not know/Do not wish to answer & 5 & 9,8 \\
\hline Total & 51 & 100,0 \\
\hline
\end{tabular}

The results of Table 11 and Table 13 reinforce the position of those who have called attention to the necessity of strengthening training and education on academic integrity.

Together with the previous question, we asked whether the institution has a designated person/body in place that deals with determining policy, promoting, and teaching academic integrity (including plagiarism), that students, teachers, and researchers can turn to. Table 14 shows the results. From the text response of the 25 "Yes" answers, it became clear that in many cases such a body is in the process of being created, or 
this task is a deputy-rector or deacon level responsibility. A single institution wrote that they have this kind of organizational unit, thus, this is the only institution where students have a clear option available outside of their teachers and perhaps the library.

Table 14

Does the institution have a person/body in charge of dealing with academic integrity?

\begin{tabular}{|l|c|c|}
\hline Possible answers & Frequency & Percent \\
\hline Yes & 25 & 49,0 \\
\hline No & 20 & 39,2 \\
\hline I do not know & 6 & 11,8 \\
\hline Total & 51 & 100,0 \\
\hline
\end{tabular}

\section{Institutional storage of students' theses (diploma work)}

Referring back to the earlier plagiarism scandals, there were cases in which the theses of relevant politically exposed persons disappeared from university libraries.

Regarding the questions on this topic, it is important to mention the legal uncertainty around academic theses. Within the Act CCIV of 2011 on National Higher Education, the rules on $\mathrm{PhD}$ theses are clear, however, the rules on theses submitted at the undergraduate and graduate level are much less so. The length of time that these papers are required to be stored is also unclear.

This part of the survey was designed to investigate in what form various institutions expect their students to submit their theses, and in what manner and for how long these papers are then stored. (Table 15, 16) What procedures are followed, what laws and internal rules do they base these on? The respondents were asked to mark which laws and internal rules the institution bases its procedures on.

Table 15

In what form must students submit their academic thesis?

\begin{tabular}{|l|c|c|}
\hline Possible answers & Frequency & Percent \\
\hline Only on paper (bound) & 2 & 3,9 \\
\hline Only electronically & 5 & 9,8 \\
\hline Both on paper and electronically & 44 & 86,3 \\
\hline Total & 51 & 100,0 \\
\hline
\end{tabular}

In the case of 5 respondents, they only ask for theses electronically, which is adequate for the requirements of the modern age, but further investigation is required into how they ensure the authenticity of the document. 
Table 16

Form of storage of student theses at the institution

\begin{tabular}{|l|c|c|}
\hline Possible answers & Frequency & Percent \\
\hline Only on paper & 4 & 7,8 \\
\hline Only electronically & 10 & 19,6 \\
\hline Both on paper and electronically & 37 & 72,5 \\
\hline Total & 51 & 100,0 \\
\hline
\end{tabular}

Similarly, to the first question, it is worth looking into how the institutions that store the documents only in electronic form ensure authenticity, especially long-term authenticity.

Beyond what is necessary for the administration of giving the diploma, respondents were asked whether finished papers are categorized in the institution's library system at the metadata level. Table 17 shows the responses.

Table 17

Does metadata-level categorization happen in the institution's library catalogue system?

\begin{tabular}{|l|c|c|}
\hline Possible answers & Frequency & Percent \\
\hline Yes & 32 & 62,7 \\
\hline No & 19 & 37,3 \\
\hline Total & 51 & 100,0 \\
\hline
\end{tabular}

4 institutions store submitted documents on paper only ( 3 for an indefinite time, 1 for more than 10 years). 47 institutions responded that the papers are stored in full-text form, at least electronically. These institutions were then asked how long they store the papers in electronic form.

Table 18 shows the length of storage of papers in electronic form.

Table 18

Length of storage of papers in electronic form

\begin{tabular}{|l|c|c|}
\hline Possible answers & Frequency & Percent \\
\hline $1-2$ years & 1 & 2,1 \\
\hline 3-5 years & 1 & 2,1 \\
\hline More than 10 years, but not indefinitely & 7 & 14,9 \\
\hline Indefinitely & 38 & 80,9 \\
\hline Total & 47 & 100,0 \\
\hline
\end{tabular}

Table 19

Papers submitted to the institution are stored in full-text form.

\begin{tabular}{|l|c|c|}
\hline Possible answers & Frequency & Percent \\
\hline Yes, BUT they are not made available electronically. & 26 & 57,8 \\
\hline Yes, AND they are made available electronically. & 16 & 35,6 \\
\hline I do not know & 3 & 6,7 \\
\hline Total & 45 & 100,0 \\
\hline
\end{tabular}


On the question of whether the submitted papers are stored in full-text form, 45 institutions responded (of the respondents 1 institution only asks for and stores documents on paper, thus, for example, they are not available in scanned form either). Of those that answered no, 4 store the theses on paper only, 2 store them both on paper and electronically. 3 do not know, 16 make them available to be accessed. The stored electronic copies are not made available to be accessed through the library repository by 26 institutions. (Based on cross-analysis of further data, it became clear that 17 of these institutions do not have a central repository.)

The following table shows in what manner the available papers can be accessed by interested parties (with the exception of papers required to be secret/classified).

Table 20

Accessibility of papers stored electronically and in full-text form.

\begin{tabular}{|l|c|c|}
\hline Possible answers & Frequency & Percent \\
\hline Through a dedicated internal computer & 8 & 50,0 \\
\hline Through an internal network & 6 & 37,5 \\
\hline Through the internet by anybody & 2 & 12,5 \\
\hline Total & 16 & 100,0 \\
\hline
\end{tabular}

In the following subsection of the survey, respondents were asked whether the institution has a central repository (with a document server) through which theses and other publications by the institution can be accessed.

Table 21

Supply of institutional repositories

\begin{tabular}{|l|c|c|}
\hline Possible answers & Frequency & Percent \\
\hline Yes, central repository & 17 & 33,3 \\
\hline Yes, multiple independent repositories of various types & 6 & 11,8 \\
\hline No & 26 & 51,0 \\
\hline Other & 2 & 3,9 \\
\hline Total & 51 & 100,0 \\
\hline
\end{tabular}

Surprisingly, 26 institutions responded that they do not have a central repository. This supports the earlier answer (Table 19), that electronically stored papers cannot be made available in such a way. The two "Other" responses indicated unique systems that had become outdated.

With the following question, we were interested to know whether the institutions know of two centrally operated systems in the neighbouring countries of Slovakia and Slovenia, as mentioned above, that provides full-text open-access and conduct text-matching at the national level. The question did not directly refer to these two solutions, instead, it was stated in general terms, thus making it suitable for the uncovering of other solutions. "Are you familiar with an internationally developed (national-level) central portal (repository), that provides full-text open-access for BSc and MSc theses, $\mathrm{PhD}$ dissertations and habilitation evaluations, published in the given country?" Table 22 shows the responses about knowledge of national repositories. 
15 institutions responded with "yes", however, none of the text responses met the full criteria posed in the question, and the Slovakian/Slovenian example was not mentioned.

Table 22

Knowledge of national repositories

\begin{tabular}{|l|c|c|}
\hline Possible answers & Frequency & Percent \\
\hline Yes & 15 & 29,4 \\
\hline No & 36 & 70,6 \\
\hline Total & 51 & 100,0 \\
\hline
\end{tabular}

With the following question, respondents were asked how open institutions of higher education are to the creation of a national repository. "Would your institution support a central portal (repository) that would make openly-accessible all BSc/MSc theses, PhD dissertations and habilitation evaluations, that are published in Hungarian higher education."

Table 23

Support for a Central Repository

\begin{tabular}{|l|c|c|}
\hline Possible answers & Frequency & Percent \\
\hline Yes & 26 & 53,1 \\
\hline No & 3 & 6,1 \\
\hline It is unfeasible & 5 & 10,2 \\
\hline I cannot/Do not wish to respond & 15 & 30,6 \\
\hline Total & 49 & 100,0 \\
\hline Did not respond & 2 & \\
\hline
\end{tabular}

Of the 26 respondents who answered "Yes", 13 further expressed their opinion in text. The common themes of the text responses were that such a repository would increase coordination, cooperation, transparency, and improve the flow of information. They deemed it much more efficient from a cost perspective, although a few see it being implemented alongside their current repositories. The question did not address the possibilities of a text-matching service on purpose, regardless, the search for plagiarism was mentioned in many responses. Some responses singled out the potential of such a central system to solve issues of plagiarism. There were also two institutions that expressed their support for Open Science and any such initiatives.

Out of the 3 "No" responses, two were accompanied by a text response. One supports the ability to search institutional repositories in aggregate, ex. Dart-Europe. The other respondent stated they would not support a central repository as "it would increase the opportunity to plagiarize", in their opinion.

Out of the 5 responses that deemed the project impossible, 4 provided text explanations, which mentioned differing institutional traditions, particular institutional interests, and lack of institutional capacity as reasons. Furthermore, it was mentioned that theses at the undergraduate and graduate level are not necessarily mature enough to be made openly available. 
The number of "I cannot/Do not wish to respond" answers was the highest for this question ( $n=15)$. Of the 26 institutions that provided a "Yes" answer, 16 have their own repository, while 10 do not.

\section{Use of a plagiarism-checking system}

In the third section of the survey, the questions were on the topic of text-matching programs. The initial step was to ask how many institutions currently use plagiarismchecking software, and how many have plans to acquire such software. This was then followed up with a theoretical question, asking for opinions on the implementation of a plagiarism-checking software at the national level.

The first question was whether the institution uses a plagiarism-checking system (financed by the institution and mandatory to use). Beyond the simple "No" answer, there were three further responses that allowed for more nuance in understanding the lack of use.

Table 24

Use of plagiarism-checking software by the institution

\begin{tabular}{|l|c|c|}
\hline Possible answers & Frequency & Percent \\
\hline Yes & 17 & 33,3 \\
\hline No & 15 & 29,4 \\
\hline No, but there are plans to acquire and implement in the future & 10 & 19,6 \\
\hline No, but due to a lack of resources, would use if possible & 7 & 13,7 \\
\hline No, and do not plan to use in the future & 2 & 3,9 \\
\hline Total & 51 & 100,0 \\
\hline
\end{tabular}

The responses show that 17 out of the 51 institutions use a plagiarism-checking system, and only 3 of these have licences for the entirety of their student body.

In the responses (Table 25) from an earlier section of the survey titled: "There are available digital, or other, tools at the institution that help in discovering plagiarism., there were 24 "Yes" answers. The contrast with the 17 "Yes" responses to the current question is explained in the text responses. In those institutions where there "are available digital tools" but no plagiarism-checking system, teachers individually use various web search engines or free-use plagiarism-checkers.

Table 25

There are available digital, or other, tools at the institution that help in discovering plagiarism.

\begin{tabular}{|l|c|c|}
\hline Possible answers & Frequency & Percent \\
\hline Yes & 24 & 47,1 \\
\hline No & 25 & 49,0 \\
\hline I do not know & 2 & 3,9 \\
\hline Total & 51 & 100,0 \\
\hline
\end{tabular}

The 17 institutions that consistently use a plagiarism-checking system received further questions regarding their currently used software and methods of use. The plagiarism-checking software was typically used to check Hungarian-language (88.2\%) 
and English-language (94.1\%) documents. The most often checked documents are: undergraduate theses (76.5\%), graduate theses (82.4\%), PhD dissertations (58.8\%), and professional articles in institutional publications (47.1\%).

In the final section of the survey, the questions were once more addressed to all institutions and were not mandatory. These questions asked about institutional needs and expectations regarding plagiarism-checking software, and thus were answerable by all institutions, regardless of whether they currently use such software, or plan to implement or not it in the future.

The presentation of the results of this section of the survey has been omitted, as they go beyond the limits of this study. The goal is to investigate the currently implemented rules, procedures, and tools in Hungarian higher education in the field of academic integrity.

\section{Conclusion}

In many cases, academic integrity is viewed similarly to digital literacy, in that one is expected to be familiar with it by default. However, neither of these skills can be learned without proper education. This study is the first undertaking of its kind in Hungary, a statistical overview of the practices of Hungarian higher education institutions regarding academic integrity. The study was conducted at the leadership level of these institutions, it did not gather data from teachers or students. Plagiarismchecking at the institutions in question is investigated in this study, as a component of the broader field of academic integrity. The large amount of data collected over the course of this study provides both the opportunity and the impetus for further research on this topic. The results and correlations show by this study indicate that there is much to be done in this field, but it is clear that Hungarian higher education institutions are on board with working together and moving forward.

\section{Acknowledgements}

The author would like to sincerely thank the following individuals and organizations for their help in this project. Irene Glendinning, for making available the surveys from previous studies, and for encouraging me to conduct this research. The ENAI, for valuable knowledge and help in the field of academic integrity. The HRC working group members, who helped in improving the survey. The HRC, which helped in reaching the many institutions included in the project. The survey respondents, who put much time and effort into providing valuable data. Thank you to the Department for Training in Higher Education, Ministry for Innovation and Technology, for giving me access to the necessary institutional statistical data. Thank you to András Vaski, for helping with English-language editing. And last but not least, thank you to Nóra, who supported my work throughout the entire process.

\section{References}

Act CCIV of 2011 on National Higher Education. (2011). Retrieved from http://njt.hu/cgi_bin/njt_doc.cgi?docid=142941.377300 
Educational Authority. (2019, August 6). Higher Education Institutions in Hungary (Âllamilag elismert felsőoktatási intézmények). Retrieved March 17, 2020, from https://www.oktatas.hu/felsooktatas/kozerdeku_adatok/felsooktatasi_adatok_kozzetetele/ felsooktatasi_intezmenyek/allamilag_elismert_felsookt_int

FÉsüs, L. (2014). Science Ethics in Hungary and Europe: Challenges and Responses (Tudományetikai kihívások és válaszok hazánkban és Európában). Magyar Tudomány, 175(6), 645-650. Retrieved from http://epa.oszk.hu/oo6oo/oo691/o0129/pdf/EPAoo691_mtud_2014_o6_645-650.pdf

Future of Higher Education Research Centre (FHERC) at Budapest Business School (BBS). (n.d.). Student Cheating and Academic Integrity. Retrieved February 17, 2020, from https:

//future-higher-education.com/publications/student-cheating-and-academic-integrity/

GLEndinning, I. (2013). Plagiarism Policies in Hungary. Retrieved from http://plagiarism.cz/ippheae/ files/D2-3-13\%20HU\%2ORT\%2OIPPHEAE\%20CU\%20Survey\%20HungaryNarrative.pdf

Hungarian Rectors Conference. (2015). Hungarian higher education, 2015. Retrieved from http://wWw.mrk.hu/wp-content/themes/mrk/documents/hungarian_higher_education_2015.pdf

International Center for Academic Integrity. (n.d.). Academic Integrity Rating System. Retrieved November 17, 2019, from https://academicintegrity.org/academic-integrity-rating-system-ai/

IPPHEAE (2013). The Impact of Policies for Plagiarism in Higher Education Across Europe Retrieved from http://plagiarism.cz/ippheae/

Mezey, B. (2014). Issues on Ethics of Science in the Hungarian Higher Education (A tudományetikai felelősség kérdései a magyar felsőoktatásban. Az egyetemi és tudományos élet etikai szabályozása - az egyetemi etikai kódexek). Magyar Tudomány, 175(6), 655-664. Retrieved from http://epa.oszk.hu/oo6oo/oo691/oo129/pdf/EPAoo691_mtud_2014_o6_655-664.pdf

Ojsteršek, M., Brezovnik, J., Kotar, M., Ferme, M., Hrovat, G., Bregant, A., \& Borovič, M. (2014). Establishing of a Slovenian open access infrastructure: a technical point of view. Program, $48(4)$, 394-412. https://doi.org/10.1108/prog-02-2014-0005

SEEPPAI (2017). South East European Project on Policies for Academic Integrity Retrieved from http://plagiarism.cz/seeppai/

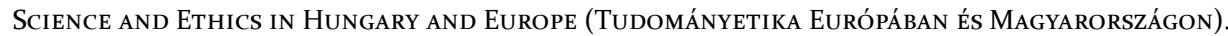
(2013). Retrieved March 16, 2020, from http://old.mta.hu/mta_hirei/ az-mta-europaban-elsokent-alkotta-meg-tudomanyetikai-kodexet-132816/

Tuhkanen, T. (n.d.). Electronic Detection of Plagiarism in Finnish Higher Education Institutions 2013. Retrieved from https://confluence.csc.fi/download/attachments/66690545/electronic_ detection_of_plagiarism_in_finnish_higher_education_institutions_2013.pdf

\section{Author}

Gabor Laszlo, University of Public Service, Faculty of Public Governance and International Studies, Department of Public Management and Information Technology, 2 Ludovika tér, $\mathrm{H}-1083$ Budapest, Hungary, e-mail: laszlo.gabor@uni-nke.hu 